\title{
Prevalence of Gram-Positive Bacteria Isolated from Nasal Swabs and Hands of Healthy Army Trainees in the Republic of Korea
}

\author{
Dae-Seong Yu ${ }^{1, \$, *}$, Sung-Bae Park ${ }^{2,3, \$, *}$, Heechul Park ${ }^{2,3, *}$, Jun Seong Kim ${ }^{2,3, *}$, Jiyoung Lee ${ }^{2, * *}$, \\ Jaewon Lim ${ }^{4, * * *}$, Young-Kwon Kim ${ }^{1, * * *}$, Jungho Kim ${ }^{2, \dagger, * * *}$ and Sunghyun $\mathrm{Kim}^{2,3, ;, * * *}$ \\ ${ }^{1}$ Department of Health Sciences, The Graduate School of Konyang University, Daejeon 35365, Korea \\ ${ }^{2}$ Department of Clinical Laboratory Science, College of Health Sciences, \\ Catholic University of Pusan, Busan 46252, Korea \\ ${ }^{3}$ Clinical Trial Specialist Program for In Vitro Diagnostics, Brain Busan 21 Plus Program, \\ The Graduate School, Catholic University of Pusan, Busan 46252, Korea \\ ${ }^{4}$ Department of Clinical Laboratory Science, College of Medicine and Science, \\ Daegu Hanny University, Kyungsan 38610, Korea
}

Skin and soft tissue infections caused by methicillin-resistant Staphylococcus aureus (MRSA) can occur especially in community populations such as military training camps. We investigated antimicrobial resistance patterns and molecular epidemiological characteristics of MRSA isolated from nasal swabs in healthy army trainees. From January 2018 to March 2018, one MRSA strain was isolated from nasal swab and hand of healthy army trainees. mecA gene detection, SCCmec and mec complex typing were performed to analyze the antimicrobial resistance patterns and molecular epidemiological characteristics of MRSA isolates. As a result, SCCmec and mec complex type of MRSA isolate from military trainees was not-typeable $(n=1)$. In conclusion, not-typeable subtype of MRSA isolate from military trainees need to be confirmed by continuous follow-up study to determine whether there is a different genotype or a new subtype of genotype present in the Republic of Korea.

Key Words: Staphylococcus aureus, Methicillin-resistant Staphylococcus aureus (MRSA), Military trainee, Molecular epidemiology

\footnotetext{
피부는 외부의 유해한 자극에 대해 방어하는 1 차적 장 벽 기능을 하며 외부 환경에 직접적으로 노출되어 있다. 피부 질환을 발생시키는 피부 상재균은 종류에 따라 심 각한 염증을 유발시킬 수 있기 때문에, 미생물에 대한 각 별한 관리가 필요하다(Bae et al., 2014). 피부 상재균으로
}

\begin{abstract}
그람양성균인 황색포도알균(Staphylococcus aureus)은 자연 계에 널리 분포하고 있으며, 건강인의 약 $30 ~ 60 \%$ 가 $S$. aureus 를 보유하고 있으며, 그 중 $10 \sim 35 \%$ 는 비강 입구 부위(anterior nares)에 장기간 집락화 할 수 있는 가능성을 지니고 있다(Park et al., 2006; Williams, 1963). 건강한 사람
\end{abstract}

Received: June 26, 2020 / Revised: August 12, 2020 / Accepted: August 18, 2020

* Graduate student, ${ }^{* *}$ Post-Doctor, ${ }^{* * *}$ Professor.

${ }^{\S}$ These authors have contributed equally.

${ }^{\dagger}$ Corresponding author: Sunghyun Kim. Department of Clinical Laboratory Science, College of Health Sciences, Catholic University of Pusan, Busan 46252, Korea.

Tel: +82-51-51-510-0560, Fax:+82-51-510-0568, e-mail: shkim0423@cup.ac.kr

${ }^{\dagger}$ Corresponding author: Jungho Kim. Department of Clinical Laboratory Science, College of Health Sciences, Catholic University of Pusan, Busan 46252, Korea.

Tel: +82-51-510-0660, Fax:+82-51-510-0568, e-mail: jutosa70@cup.ac.kr

(C) The Korean Society for Biomedical Laboratory Sciences. All rights reserved.

(c) This is an Open Access article distributed under the terms of the Creative Commons Attribution Non-Commercial License (http://creativecommons.org/licenses/by-nc/3.0/) which permits unrestricted non-commercial use, distribution, and reproduction in any medium, provided the original work is properly cited. 
에게 상재하는 정상세균이지만, 적당한 환경이 주어지면 여러 가지 질병을 일으키는 기회감염균이다(Timoney et al., 1988). S. aureus는 병원성이 강하고 조직 침습성이 높아 지역사회감염과 병원내감염의 중요한 원인균으로 알려져 있으며, 연조직이나 피부감염, 농양, 창상감염 및 폐렴 과 균혈증 등을 유발하는 것으로 보고 되었다(Archer and Mayhall, 1983; Bouvet et al., 1990).

Methicillin-resistant Staphylococcus aureus (MRSA) 및 Coagulase-negative staphylococci (CoNS)의 주요 내성 기전 은 mecA 유전자의 획득에 의해 Penicillin-binding protein 2 (PBP 2)의 변이형인 PBP 2a를 생성하면 모든 $\beta$-lactam계 항생제와의 결합 친화도는 감소하는 것으로 알려져 있다. MRSA의 경우 다재 내성을 나타내는 경우가 많이 보이고 있으며, 더욱이 2000 년대에 들어 지역사회 MRSA의 감염 증의 보고가 눈에 띄게 증가하고 있어, MRSA 감염치료 에 이용할 수 있는 항생제는 제한적이다(Chambers, 1997). $\mathrm{MRSA}$ 의 분리 및 전파는 일반적인 지역사회에서 뿐만 아 니라, 지속적으로 집단생활을 하고 있는 군 부대 내에서 도 큰 관심사가 되고 있다. 집단생활을 하는 군 부대 내 에서 $\mathrm{MRSA}$ 의 보균 및 감염은 훈련 중 외상이 발생할 경 우 피부와 연조직 감염 등으로 인한 군의 전술적 측면에 서 막대한 손실을 가져올 수 있기 때문에 사전에 집단생 활 환경의 청결 유지 및 $\mathrm{MRSA}$ 에 대한 감염관리가 매우 중요하게 여겨지고 있다. 최근에는 MRSA 감염이 지역사 회의 공동생활 환경에서 쉽게 전파되고 있어 지역사회 관련 MRSA 감염에 따른 유행성 균주의 출현에 대한 역 학적 연구가 활발히 진행되고 있다(Bae et al., 2010; Kim et al., 2007). 그러나 군대 내에서 MRSA에 대한 연구, 항 생제 내성 기전 및 조절 유전자들의 역할에 대한 연구가 부족한 실정이다. 또한, MRSA 감염이 지역별로 어느 정 도 상재하고 있는지, 내성 관련 유전자 및 항생제 내성 양상 등에 대한 조사가 선행되어야 이에 대한 예방이나 치료 방향의 설정이 이루어 질 수 있을 것이다.

$\mathrm{MRSA}$ 의 감염에 의해 야기되는 피부와 연조직 감염은 집단생활을 하는 사람들에게서 많이 발생되고 있으며 특 히, 대부분의 시간 동안 집단생활을 하는 군인들의 발병 률은 신병들에게서 가장 높게 나타나는 것으로 보고되었 다(Landrum et al., 2012). 또한, 2014년 수행된 미국 군 훈련 병에서의 MRSA 분포율 연구 결과에 따르면, 미 육군의 가장 큰 훈련 기지인 조지아의 포트 베닝(Fort Benning, Georgia)에서는 기초 군사훈련 동안 훈련병 10 명 중 거의 1 명(약 $10 \%)$ 에게서 피부와 연조직 감염이 발생되었는데,
원인균의 대다수가 MRSA로 밝혀졌으며, 추가적인 연간 조사 결과 1,000 명 중 42 명(약 $4 \%$ )이 MRSA 감염에 의한 피부와 연조직 감염인 것으로 집계되었다(Leamer et al., 2013; Morrison-Rodriguez et al., 2010). 피부와 연조직 감염 은 신병들의 훈련 참석률을 저조하게 할 뿐만 아니라 성 공적인 훈련 달성을 약화시키기 때문에 군에서는 각별히 관심을 갖고 집단감염을 철저히 예방해야 하는 주요 질 환 중 하나이다. 군에서도 MRSA의 감염 예방을 위해 자 체적인 대책을 수립하여 적용하고는 있지만, 군 의료기관 내 장병들에게만 국한되어 있는 실정이고, 비 의료기관인 일반 부대 장병들, 특히 훈련기관에서는 교육훈련 위주의 생활로 인해 MRSA 감염 예방에 대한 관심이 극히 저조 하다 보니 관련 대책 또한 미흡한 실정이다. 이러한 점을 비추어 볼 때, 우리나라의 건강한 군 훈련병에서의 MRSA 감염율 조사는 큰 의미가 있다고 볼 수 있다. 또한, $\mathrm{SCC}$ $m e c$ 형의 특성에 따라 병원감염 MRSA와 지역사회 관련 MRSA 균주의 연관성이 알려져 있어, 이 균주의 역학적 연구에 SCCmec 유형 분석이 많이 이용되고 있다(Cha et al., 2009).

따라서, 본 연구에서는 집단생활을 하고 있는 국내의 군 훈련병에서 분리된 MRSA 분리 배양 균주를 대상으 로 분자유전학적인 분석을 통해 $m e c \mathrm{~A}$ 유전자를 검출하고, Staphylococcal cassette chromosome (SCC) mec typing과 mec complex typing을 시행하여, 각 MRSA 분리 배양 균주의 아형을 분석하여 그 분자생물학적 특성을 분석함으로써, 군 훈련병과 군 부대 내 집단생활에서의 감염관리를 위한 기초 자료를 제공하고자 하였다.

2018년 1월부터 3월까지 시료 채취 시의 군의관의 소 견을 바탕으로 건강한 군 훈련병 총 40 명의 비강과 손 에서 각각 40 개의 시료를 채취하여 세균 분리를 시도하 였다. 분리 배양된 총 60 개의 분리 배양 균주 중 1 개의 $\mathrm{MRSA}$ 를 대상으로 $\mathrm{SCCmec}$ 과 mec complex 아형의 분자유 전학적 특성을 분석하기 위해, 모든 검체는 혈액한천배지 (Blood agar plate, BAP) (BNF KOREA, Gimpo, Korea)에 접 종하여 $37^{\circ} \mathrm{C}$ 에서 $18 \sim 24$ 시간 배양하였다. 단일 집락으로 분리된 세균은 Gram 염색 후, MicroScan WalkAway-96 자 동화 동정 시스템(Beckman Coulter, West Sacramento, CA, $\mathrm{USA}$ )을 이용해 세균 종 및 항생제 감수성 검사를 시행하 였다. 항생제 감수성 시험 시행 후 감수성과 내성 여부의 판정은 Clinical and Laboratory Standards Institute (CLSI, Wayne, PA, USA) 가이드라인(CLSIM100 S26 (CLSI M45$\mathrm{A} 2)$ )에서 권고하는 표준 값을 적용하여 실시하였다. 결 
Table 1. Biochemical identification results of bacteria isolated from nasal swab and hand of healthy army trainees

\begin{tabular}{lcccccc}
\hline \hline \multirow{2}{*}{$\begin{array}{l}\text { Sample } \\
\text { collection site }\end{array}$} & \multicolumn{5}{c}{ Number of isolates, $\mathrm{n}(\%)$} \\
\cline { 2 - 5 } & MRSA & MSSA & CoNS & Bacillus & Corynebacterium \\
spp. & Spp. & Total \\
\cline { 2 - 6 } Nasal cavity & $1(3.8 \%)$ & $13(50.0 \%)$ & $12(46.2 \%)$ & $0(0.0 \%)$ & $0(0.0 \%)$ & $26(100.0 \%)$ \\
Hand & $0(0.0 \%)$ & $11(32.4 \%)$ & $18(52.9 \%)$ & $3(8.8 \%)$ & $2(5.9 \%)$ & $34(100.0 \%)$ \\
\hline Total & 1 & 24 & 30 & 3 & 2 & 60 \\
\hline
\end{tabular}

MRSA: Methicillin-resistant Staphylococcus aureus; MSSA: Methicillin-sensitive Staphylococcus aureus; CoNS: Coagulase-negative Staphylococci

Table 2. Comparison of SCCmec \& mec complex subtypes of MRSA isolates from nasal swab of healthy army trainees

\begin{tabular}{|c|c|c|c|c|c|c|c|c|c|c|c|}
\hline \multirow{2}{*}{ Strain } & \multirow{2}{*}{ mecA gene } & \multicolumn{2}{|c|}{ mec complex subtypes } & \multicolumn{8}{|c|}{ SCCmec subtypes } \\
\hline & & Group A & Group B & I & II & III & IVa & $\mathrm{IVb}$ & IVc & $\mathrm{IVd}$ & $\mathrm{V}$ \\
\hline HAT-MRSA & + & - & - & - & - & - & - & - & - & - & - \\
\hline
\end{tabular}

HAT-MRSA: MRSA isolated from healthy army trainee

+: Positive; -: Negative

과의 정확도를 위해 표준 균주인 S. aureus ATCC 29213을 사용하여 주 1 회 임상검체와 동일한 방법으로 항생제 감수성 시험을 실시하여 CLSI 기준 허용범위에 적절한 지 확인하였다. 항생제 감수성 시험에 사용된 항생제는 azithromycin, $\beta$-lactams, ciprofloxacin, clindamycin, daptomycin, erythromycin, fosfomycin, fusidic acid, gentamicin, levofloxacin, linezolid, moxifloxacin, mupirocin, rifampin, synercid, teicoplanin, tetracycline, trimethoprim-sulfamethoxazole, vancomycin 을 포함해 총 19 종이다.

$\mathrm{BAP}$ 에서 배양된 세균의 집락 1 2개를 백금이로 취한 후 5\% Chelex ${ }^{\circledR}$ Resin (Bio-Rad, Hercules, CA, USA) / TBE 용액 $500 \mu \mathrm{L}$ 에 혼탁시킨 후 $100^{\circ} \mathrm{C}$ 에서 10 분간 끓인 후 $6,032 \times \mathrm{g}$ 로 2 분간 원심분리한 상층액을 새 튜브에 옮겨 분석 시까지 $-20^{\circ} \mathrm{C}$ 에서 보관하였고, 추출한 genomic DNA (gDNA)는 Nanodrop 2,000 (Thermo Fisher Scientific, Waltham, $\mathrm{MA}, \mathrm{USA}$ ) 장비를 이용해 농도와 순도를 측정하였다. 이 후 메티실린 내성 유전자인 mecA 유전자 검출 및 $\mathrm{SCCmec}$ 과 mec complex typing을 수행하기 위해 Prime Taq PCR Premix (GeNet Bio, Daejeon, Korea) $10 \mu \mathrm{L}$, Forward Reverse primer의 농도를 각각 $10 \mathrm{pmole} / \mu \mathrm{L}$, 추출한 $\mathrm{gDNA}$ 를 주형 DNA로 $1 \mu \mathrm{L}$, 멸균 증류수 $7 \mu \mathrm{L}$ 를 첨가하여 총 $20 \mu \mathrm{L}$ 의 혼합액을 만들어 multiplex PCR을 수행하였다. 본 연구 에 사용한 primer의 염기서열은 기존 연구 자료를 바탕 으로 시행하였다(Kim et al., 2018). 증폭 반응이 끝난 PCR 산물은 $1.5 \%$ agarose gel에 전기영동 한 후 그 결과를 확
인하였다.

건강한 군 훈련병 총 40 명의 비강과 손으로부터 세균 분리 및 동정을 시도한 결과, 분리 배양된 세균 총 60 주 중 그람양성알균은 55 주 $(91.7 \%)$ 가 분리되었으며, 그 중 $S$. aureus 는 25 주(45.5\%), CoNS는 30주(54.5\%)가 분리되었다. 총 25 주의 S. aureus 중 MRSA가 1주(4\%), 메티실린 감수 성 황색포도알균(Methicillin-susceptible S. aureus, MSSA)가 24주(96\%) 분리되었다(Table 1).

본 연구에서 건강한 군 훈련병의 비강에서 분리 배양된 $\mathrm{MRSA}$ 의 $\mathrm{SCCmec}$ 과 mec complex 아형 분석 결과, 1 주의 $\mathrm{MRSA}$ 임상분리균주를 대상으로 $m e c \mathrm{~A}$ 유전자 검출을 위 한 $\mathrm{PCR}$ 을 실시한 결과 $\mathrm{MRSA}$ 로 확인된 1 주에서 $m e c \mathrm{~A}$ 유전자를 확인하였고 $\mathrm{SCCmec}$ 과 mec complex 아형 분석 결과 모두 확인되지 않는 Not-typeable 아형으로 나타났다 (Table 2).

결과를 바탕으로, 건강한 군 훈련병의 비강에 분리된 MRSA 중 SCCmec과 mec complex typing에서 not-typeable 의 결과를 나타낸 균주의 경우 추가적인 분석을 통한 후 속 연구로써 국내에 특이적으로 존재하는 다른 아형의 균주인지에 대한 연구가 필요할 것으로 사료된다. 하지만, 본 연구의 한계점은 건강한 군 훈련병 전체를 대상으로 $\mathrm{MRSA}$ 의 보균율을 조사한 것이 아니기 때문에, CA-MRSA 의 분리율이 낮았으며, 건강한 군 훈련병으로부터 분리 배양된 MRSA가 1 주로 전체 CA-MRSA의 특성을 대변 하기에는 통계학적 유의성이 낮을 수 있기 때문에 CA- 
Table 3. Comparison of phenotypic antibiotic resistance patterns of MRSA isolates according to SCCmec \& mec complex subtypes

\begin{tabular}{lccc}
\hline \hline Strains & $\begin{array}{c}\text { Phenotypic antimicrobial } \\
\text { resistance profile }\end{array}$ & $\begin{array}{c}\text { Clinical } \\
\text { diagnosis }\end{array}$ & $\begin{array}{c}\text { SCCmec \& mec complex } \\
\text { subtypes }\end{array}$ \\
\hline HAT-MRSA & AM, AUG, IMP, OX, P & No clinical diagnosis & Not-typeable \\
\hline
\end{tabular}

HAT-MRSA: MRSA isolated from healthy army trainee

AM: Ampicillin; AUG: Amox/K clav; IMP: Imipenem; OX: Oxacillin; P: Penicillin

$\mathrm{MRSA}$ 와 HA-MRSA의 분자 아형에 따른 항생제 내성 패 턴의 특성을 정확하게 비교 분석하기에는 제한점이 있을 수 있다.

추가적으로 건강한 군 훈련병의 비강에서 분리 배양 된 1 주의 MRSA 임상분리균주를 대상으로 한 항생제 감 수성 시험 결과, oxacillin을 포함하여 ampicillin, amox/K clav, imipenem, penicillin에 내성을 나타냈으며, azithromycin, daptomycin, erythromycin, fosfomycin, linezolid, trimethoprim/ sulfamethoxazole 등 에는 감수성을 나타냈다(Table 3).

본 연구를 통해 건강한 군 훈련병에서 CA-MRSA가 분 리될 수 있다는 가능성을 확인할 수 있었으며, 이는 본 연구가 진행된 군 훈련기관 외에도 수많은 훈련기관과 일반 부대에서 MRSA 집단 감염으로 인한 피부와 연조직 감염 환자가 발생할 가능성이 있으며, 이로 인해 군의 전 투 및 전략 손실이 초래할 수 있다는 것을 시사한다.

군 훈련기관 내에서 MRSA 감염 환자 발생 시 이에 따른 후속조치를 실시함에 앞서 집단 단체생활 내에서 $\mathrm{MRSA}$ 의 전파를 예방할 수 있는 사전 대책을 더욱 강구 하고 적극적으로 감염의 예방을 홍보하는 것이 매우 중요 할 것으로 판단된다. 과거 신종 인플루엔자가 유행했던 이후 군에서는 전 부대에 손 소독제를 비치하고 손 씻기 등의 감염관리 교육을 실시하여 단체생활에서의 집단 감 염질환 발생의 예방을 도모하고 있지만, 이는 MRSA 감염 에 대한 직접적인 사전 예방책으로 보기에는 어렵기 때문 에, 좀 더 효과적인 MRSA 감염에 대한 예방 대책이 필 요할 것으로 사료된다. 한 선행 연구의 예로, mupirocin은 국소용 항생제로써 MRSA에 탁월한 억제 효과가 있으며, 국소 도포 후 24 36시간 후에는 살균 작용이 충분한 농 도에 이르게 된다고 알려져 있다(Casewell and Hill, 1986; Scully et al., 1992). 반면, Mupirocin 내성인 MRSA가 생길 경우, 이들 세균을 제거하는데 어려움이 있어 지역사회 감염균의 전파를 억제하는데 문제점이 제기되고 있다. Mupirocin의 사용이 증가함에 따라 mupirocin에 고도 또는 저도 내성인 포도알균 균주들이 보고되고 있다(Layton and Patterson, 1994). 따라서 피부나 연조직 감염이 유발된 지
역사회감염으로 인한 훈련병 등에 mupirocin의 예방적 도 포뿐만 아니라, 감염관리 프로그램이 제대로 이행되지 않 는 군 훈련기관에서의 지속적인 감염관리 프로그램의 필 요할 뿐만 아니라, 추후에 더 많은 인원을 대상으로 한 연구 혹은 지속적인 모니터링이 필요할 것으로 사료된다.

\section{ACKNOWLEDGEMENT}

This study was supported by BB21 plus Project in 2020, Basic Science Research Program through the National Research Foundation of Korea (NRF) funded by the Ministry of Education (2020R1A6A3A01099438) and the Center for Women In Science, Engineering and Technology (WISET) and WISET Regional Agency of PKNU Grant funded by the Ministry of Science and ICT (MSIT) under the Program for Returners into R\&D.

\section{CONFLICT OF INTEREST}

No potential conflict of interest relevant to this article was reported.

\section{REFERENCES}

Archer GL, Mayhall CG. Comparison of epidemiologic markers used in investigation of an outbreak of methicillin-resistant Staphylococcus aureus infections. J Clin Microbiol. 1983. 18: 395-399.

Bae IG, Kim JS, Kim S, Heo ST, Chang C, Lee EY. Genetic correlation of community-associated methicillin-resistant Staphylococcus aureus strains from carriers and from patients with clinical infection in one region of Korea. J Korean Med Sci. 2010. 25: 197-202.

Bae JY, Jang HN, Ha JH, Park JH, Park J, Park SN. Antimicrobial activities of licorice extracts from various contries of origin according to extraction conditions. Korean J Microbiol Biotechnol. 2014. 42: 361-366.

Bouvet A, Fournier JM, Audurier A, Branger C, Orsoni A, Girard C. 
Epidemiological markers for epidemic strain and carrier isolates in an outbreak of nosocomial oxacillin-resistant Staphylococcus aureus. J Clin Microbiol. 1990. 28: 1338-1341.

Casewell MW, Hill RL. Elimination of nasal carriage of Staphylococcus aureus with mupirocin ("pseudomonic acid")-a controlled study. J Antimicrob Chemother. 1986. 17: 365-372.

Cha EK, Chang KA, Hwang SM. Correlation between staphylococcal cassette chromosome mec type and coagulase serotype of methicillin-resistant Staphylococcus aureus. J Bacteriol Virol. 2009. 39: 71-78.

Chambers HF. Methicillin resistance in Staphylococci: molecular and biochemical basis and clinical implications. Clin Microbiol Rev. 1997. 10: 781-791.

Kim ES, Song JS, Lee HJ, Choe PG, Park KH, Cho JH, et al. A survey of community-associated methicillin-resistant Staphylococcus aureus in Korea. J Antimicrob Chemother. 2007. 60: 1108-1114.

Kim HS, Park SB, Kim SH, Kim S, Hyun SH, Kim YK. Molecular genetic characteristics of methicillin-resistant Staphylococcus aureus isolated from patients and environment of general hospital intensive care unit in a Chungnam province, Korea. Korean J Clin Lab Sci. 2018. 50: 110-117.

Landrum MI, Neumann C, Cook C, Chukwuma U, Ellis MW, Hospenthal DR, et al. Epidemiology of Staphylococcus aureus blood and skin and soft tissue infections in the US military health system, 2005-2010. JAMA. 2012. 308: 50-59.

Layton MC, Patterson JE. Mupirocin resistance among consecutive isolates of oxacillin-resistant and borderline oxacillin-resistant Staphylococcus aureus at a university hospital. Antimicrob
Agents Chemother. 1994. 38: 1664-1667.

Leamer NK, Clemmons NS, Jordan NN, Pacha LA. Update: community-acquired methicillin-resistant Staphylococcus aureus skin tissue infection surveillance among active duty military personnel at Fort Benning GA, 2008-2010. Mil Med 2013. 178: 914-920.

Morrison-Rodriguez SM, Pacha LA, Patrick JE, Jordan NN. Community-associated methicillin-resistant Staphylococcus aureus infections at an army training installation. Epidemiol Infec. 2010. 138: 721-729.

Park JY, Kim SD, Lee JS. Infection of methicillin-resistant $S$ aureus nasal carriage in the community pediatric population. Korean J Epidemiol. 2006. 28: 171-181.

Scully BE, Briones F, Gu JW, Neu HC. Mupirocin treatment of nasal staphylococcal colonization. Arch Intern Med. 1992 152: 353-356.

Timoney JF, Gillespie JH, Scott FW, Barlough JE. Hagan and Bruner's microbiology and infectious disease of domestic animals. Comstock Publishing Associates. 1988: 171-196.

Williams RE. Healthy carriage of Staphylococcus aureus: its prevalence and importance. Bacteriol Rev. 1963. 27: 56-71.

https://doi.org/10.15616/BSL.2020.26.3.244

Cite this article as: Yu DS, Park SB, Park H, Kim JS, Lee J, Lim J, Kim YK, Kim J, Kim S. Prevalence of Gram-Positive Bacteria Isolated from Nasal Swabs and Hands of Healthy Army Trainees in the Republic of Korea. Biomedical Science Letters. 2020. 26: 244-248. 